Doi: HTTPS://DOI.ORG/10.23910/2/2021.0415h

\title{
Effects of Sowing Dates on Yield and Yield Components of Different Varieties of Wheat (Triticum aestivum L.) in Western Uttar Pradesh
}

\author{
Y. P. Singh, Satybhan Singh, V. K. Dhangrah* and Tripuresh Mishra
}

School of Agricultural Sciences \& Engineering, IFTM University, Moradabad, U.P. (244 102), India

\section{Corresponding Author}

V. K. Dhangrah

e-mail: vinod.dhangrah@gmail.com

\author{
Article History \\ Article ID: IJEP0415h \\ Received on $02^{\text {nd }}$ April, 2021 \\ Received in revised form on $18^{\text {th }}$ October, 2021 \\ Accepted in final form on $10^{\text {th }}$ November, 2021
}

\begin{abstract}
An experiment was conducted during Rabi season (November-December) of 2018-19 to study the effect of three dates of sowing (26 November, $11^{\text {th }}$ December and $25^{\text {th }}$ December) on growth, yield attributes and yield of fivewheat varieties (HD-2967, HD-3086, WH-1105, PBW-343 and PBW-226) at Agricultural Research Farm of IFTM University, Moradabad (UP) India. The experiment was laid out in Factorial Randomized Design with two replications. Sowing was done at spacing of $22.5 \mathrm{~cm}$ in sandy loam soil. The observations were recorded on growth, flowering, maturity, yield and yield components. Analysis of variance showed the significant variations were observed for the characters viz. plant height, days to flowering, spikes per plant, days to maturity, grain yield, test weight, straw yield, biological yield and harvest index due to changing dates of sowing. However, varietal variations were recorded for plant height, days to flowering, spikes per plant, days to maturity and test weight. Wheat sown on $26^{\text {th }}$ November recorded significant increase in plant height, tillers plant ${ }^{-1}$, spikes ${ }^{-1}$ plant, grain yield and straw yield over late sowing on $11^{\text {th }}$ December and $25^{\text {th }}$ December. There was no significant variation among varieties for yield and yield contributing traits such as grains spike ${ }^{-1}$, grain and straw yield. Significant interaction effects between dates of sowing and varieties were found for days to flowering which showed that the variety HD-2967 is as best wheat variety for early sown and PBW-226 for late sown conditions in order to obtain better returns.
\end{abstract}

Keywords: Growth, sowing dates, varieties, wheat, yield

\section{Introduction}

Wheat (Triticum aestivum L.) is one of the major food grain crops of the world including India. India produced about 96.16 million tonnes of wheat form an area of 30.33 million hectares with an average productivity of $3171 \mathrm{~kg} \mathrm{ha}^{-1}$ (DES, 2020). Uttar Pradesh, which is one of the major wheat growing states, produced 32.59 million tonnes of wheat from 9.50 million hectares area ((DES, 2020). The influence of planting dates on productivity of agronomic crops assumes pivotal significance. Planting date is determined through occurrence of weeds, diseases and pests attacks, and temperature of soil and environment. The sowing date defines the environmental conditions to which the crop will be exposed in key moments of its developmental cycle (e.g., critical periods for yield and quality components). An appropriate planting time is different in various agroecological conditions. Optimum sowing date enhanced yield components and yield to ensure food security worldwide (Abbas et al., 2019). Proper time of sowing helps cultivars to express its growth patterns to its full extent in a diverse setting of environmental dynamic beside genotype environmental interaction as it also helps scientist of particular environment (area) for maximizing the yield (Shah et al., 2006). Some researcher reported that wheat sown between 15$30^{\text {th }}$ November gave more grain yield (Kumar et al., 2000; Akhtar et al., 2006). Appropriate sowing time of various field crops results in higher economic yield as it helps varieties to express their full growth potential. Thus, the sowing time of wheat crop plays a pivotal role where climatic conditions vary throughout the country and delay in sowing decreases wheat grain yield by 58.2 per cent (Ali et al., 2004). Ouda et al. (2005) reported that delay of sowing date in wheat till the end of December reduced grain yield by about $16 \%$. Late planting of wheat results poor tillering and more chances of winter injury (Joshi et al., 1992). Under late sown condition wheat crop exposed to low temperature at the germination, which delayed the crop emergence and higher temperature at the reproductive phase leads to force maturity and resulted in reduction of the yield and yield attributes (Gupta et al., 2017). Being a temperature sensitive crop, late sown crop is exposed to low temperature at the time of establishment and to high temperature at the reproductive 
phase that finally leads to accelerated maturity of crop and thus crops mature early in North Indian condition. This not only affects yield, but also affects the yield components and other aspects of the growth and development of wheat. It is generally associated with a reduced kernel weight (Radmehr et al., 2003), a reduced number of spikes per plant and per unit area (Stapper and Fischer, 1990), harvest index, grain number per spike, and leaf area index (Jessop and Ivins, 1970). Since wheat yield and end-use quality depend upon the environment, genotype, and their interaction; therefore, the present investigation was undertaken to study the effect of sowing dates on different wheat varieties.

\section{Materials and Methods}

A field experiment on wheat crop was conducted during rabi season (November-December) of 2018-2019 at the Agricultural Research Farm of IFTM University, Moradabad, Uttar Pradesh, India. The experimental site is situated in the village Lodhipur Rajput at Delhi Road NH-24, Moradabad, (U. P.) near the banks of Ram-Ganga River. This city is situated in western U.P. between $28^{\circ} 21^{\prime}$ to $28^{\circ} 16^{\prime}$ Latitude North and $78^{\circ}$ 4 ' to $79^{\circ}$ Longitude East and above mean sea level of 193.23 meters. The experimental plots have uniform topography with homogenous fertility and soilcharacteristics typical to suit wheat crops cultivation. The fields were fairly levelled and had good drainage having assured irrigation facility. Field experiment comprising of three dates of sowing, $26^{\text {th }}$
November, $11^{\text {th }}$ December and $25^{\text {th }}$ December and five varieties, HD-2967, HD-3086, WH-1105, PBW-343 and PBW226 was laid out in Factorial Randomized Design with two replications. Sowing was done at spacing of $22.5 \mathrm{~cm}$. The crop was fertilized @ 120:60:40 of $\mathrm{N}_{2}, \mathrm{P}_{2} \mathrm{O}_{5}, \mathrm{~K}_{2} \mathrm{O} \mathrm{kg} \mathrm{ha}{ }^{-1}$, of which half dose of the nitrogen, full dose of phosphorus and potassium was applied as a basal dose whereas remaining half of nitrogen was applied in two equal splits, first at CRI stage and second at maximum tillering. During the crop season, mean weekly maximum temperature ranged between $35.80^{\circ} \mathrm{C}$ to $12.28^{\circ} \mathrm{C}$ and minimum temperature between $3.0^{\circ} \mathrm{C}$ to $17.60^{\circ} \mathrm{C}$. The observations were recorded on various quantitative characters such as growth, flowering, maturity and yield parameters. The data was statistically analysed using OP-state software following the procedure fortwo factor analysis in Randomized Block Design (RBD). The standard errors of mean were calculated for each factor of investigation and critical differences (CD) at $5 \%$ level were worked out for comparing the treatment means wherever ' $F$ ' test was found significant.

\section{Results and Discussion}

Analysis of variance (Table 1) showed that significant differences were observed for the characters viz. plant height, days to flowering, spikes per plant, days to maturity, grain yield, test weight, straw yield, biological yield and harvest index due to changing dates of sowing. However, varietal

Table 1: Analysis of variance for thirteen quantitative traits of Wheat as influenced by dates of sowing and varieties

\begin{tabular}{|c|c|c|c|c|c|c|c|c|}
\hline Source of variation & DF & $\begin{array}{c}\text { Days to } \\
\text { flowering }\end{array}$ & $\begin{array}{l}\text { Plant } \\
\text { height }\end{array}$ & $\begin{array}{ll}\text { No. of til- } & \text { No } \\
\text { lers plant } & -1 \\
\text { tive }\end{array}$ & $\begin{array}{l}\text { o. of reproduc- } \\
\text { ve tillers plant }{ }^{-1}\end{array}$ & $\begin{array}{l}\text { Spike } \\
\text { plant }^{-1}\end{array}$ & $\begin{array}{l}\text { Spike } \\
\text { length }\end{array}$ & $\begin{array}{c}\text { No. of grain } \\
\text { spike }^{-1}\end{array}$ \\
\hline Dates of sowing (D) & 2 & $412.93^{* *}$ & $52.57^{* *}$ & 0.89 & 0.47 & $15.28^{* *}$ & 1.00 & 127.47 \\
\hline Variety (V) & 4 & $74.67^{* *}$ & $26.31^{* *}$ & 0.28 & 0.10 & $7.70^{* *}$ & 0.12 & 43.77 \\
\hline Interaction $(D \times V)$ & 8 & $11.27^{* *}$ & 4.02 & 0.16 & 0.21 & 0.34 & 0.44 & 18.30 \\
\hline Error & 15 & 0.50 & 2.38 & 0.35 & 0.26 & 1.37 & 0.50 & 41.05 \\
\hline \multicolumn{9}{|l|}{ Table 1: Continue... } \\
\hline Source of variation & & Days to maturity & Grain yield & Test weight & Straw yield & \multicolumn{2}{|c|}{ Biological yield } & Harvest index \\
\hline Dates of sowing (D) & & $516.13^{* *}$ & $645.90^{* *}$ & $88.21^{* *}$ & $376.06^{* *}$ & \multicolumn{2}{|c|}{$1829.61^{* *}$} & $146.88^{* *}$ \\
\hline Variety (V) & & $83.33^{* *}$ & 21.68 & 30.45 & 36.40 & \multicolumn{2}{|c|}{72.49} & 18.84 \\
\hline Interaction $(\mathrm{D} \times \mathrm{V})$ & & 0.133 & 29.86 & 4.60 & 12.96 & \multicolumn{2}{|c|}{49.56} & 16.20 \\
\hline Error & & 0.50 & 47.72 & 3.19 & 30.33 & \multicolumn{2}{|c|}{109.61} & 18.272 \\
\hline
\end{tabular}

variations were recorded for plant height, days to flowering, spikes plant ${ }^{-1}$, days to maturity and test weight. Interaction between dates of sowing and varieties were found significant for days to flowering indicating selection of varieties for different sowing dates, delay in sowing nestled early flowering that might be due to prevalence of high temperature during vegetative phase. Kumar et al. (2017) also reported significant variation for growth, flowering, maturity, yield and yield attributing traits of wheat.
The effects of sowing dates on quantities traits of wheat crop and different varieties have been presented in Table 2. Flowering in wheat was significantly affected by varied dates of sowing and varieties. Sowing done at November $26^{\text {th }}$ took significantly maximum days (91.10) to flowering which followed by $11^{\text {th }}$ December and $25^{\text {th }}$ December. Among the varieties, PBW- 226 was too early ( 80.50 days) in flowering and HD- 2967, too late (89.93 days). The flowering in plant delayed with timely sown crop because crop exposed to favourable 


\begin{tabular}{|c|c|c|c|c|c|c|c|}
\hline Source of variation & $\begin{array}{l}\text { Days to } \\
\text { flowering }\end{array}$ & $\begin{array}{l}\text { Plant } \\
\text { height }\end{array}$ & $\begin{array}{ll}\text { No. of til- } & \text { No } \\
\text { lers plant } & \text { - }\end{array}$ & $\begin{array}{l}\text { No. of reproduc- } \\
\text { ive tillers plant }{ }^{-1}\end{array}$ & $\begin{array}{l}\text { Spike } \\
\text { plant }^{-1}\end{array}$ & $\begin{array}{l}\text { Spike } \\
\text { length }\end{array}$ & $\begin{array}{l}\text { No. of grain } \\
\text { spike }^{-1}\end{array}$ \\
\hline $26^{\text {th }}$ Nov. & 91.10 & 101.42 & 6.36 & 4.76 & 7.84 & 9.05 & 48.41 \\
\hline $11^{\text {th }}$ Dec. & 88.50 & 97.63 & 5.93 & 4.64 & 6.67 & 8.56 & 55.04 \\
\hline $25^{\text {th }}$ Dec. & 78.90 & 97.29 & 6.13 & 5.64 & 6.13 & 9.15 & 54.03 \\
\hline LSD & 0.68 & 1.05 & NS & NS & 0.30 & NS & NS \\
\hline \multicolumn{8}{|l|}{ Verities } \\
\hline HD-2967 & 89.93 & 99.87 & 6.22 & 4.71 & 7.40 & 8.99 & 52.72 \\
\hline HD-3086 & 85.83 & 98.38 & 6.28 & 4.67 & 7.30 & 8.79 & 55.51 \\
\hline WH-1105 & 86.50 & 96.13 & 6.00 & 4.80 & 6.37 & 9.08 & 53.80 \\
\hline PBW-343 & 88.17 & 97.85 & 6.23 & 4.82 & 7.15 & 8.98 & 52.23 \\
\hline PBW-226 & 80.50 & 101.67 & 6.56 & 5.10 & 6.17 & 8.75 & 48.22 \\
\hline LSD & 0.88 & 1.93 & NS & NS & 0.39 & NS & NS \\
\hline \multicolumn{8}{|l|}{ Table 2: Continue... } \\
\hline Source of variation & Days to maturity & Grain yield & Test weight & Straw yield & Biolog & al yield & Harvest index \\
\hline $26^{\text {th }}$ Nov. & 126.90 & 41.51 & 38.00 & 53.28 & & 04 & 47.10 \\
\hline $11^{\text {th }}$ Dec. & 117.90 & 40.76 & 35.00 & 46.73 & & 23 & 43.23 \\
\hline $25^{\text {th }}$ Dec. & 112.70 & 27.23 & 32.06 & 41.03 & & 25 & 39.43 \\
\hline LSD & 0.68 & 6.69 & 1.72 & 5.33 & & 14 & 4.14 \\
\hline \multicolumn{8}{|l|}{ Verities } \\
\hline HD-2967 & 120.83 & 37.03 & 35.93 & 51.18 & & 20 & 41.42 \\
\hline HD-3086 & 120.83 & 39.08 & 37.88 & 46.70 & & .78 & 45.38 \\
\hline WH-1105 & 120.83 & 36.45 & 35.13 & 44.70 & & 15 & 44.63 \\
\hline PBW-343 & 120.83 & 33.78 & 34.43 & 45.85 & & 63 & 41.59 \\
\hline PBW-226 & 112.50 & 36.15 & 31.72 & 46.63 & & .78 & 43.25 \\
\hline LSD & 0.88 & NS & 2.22 & & & IS & NS \\
\hline
\end{tabular}

weather during the whole life cycle and thus the different phases of plant life could be completed at appropriate timing. Under later sown condition the plants were forced to early flowering because of sudden rise in temperature coupled with hot wind. These results are in close conformity with the finding of Gupta et al. (2017).

Dates of sowing exhibited significant differences for plant height was noticed till maturity. Maximum plant height was recorded on sowing date November $26^{\text {th }}(101.42 \mathrm{~cm})$ and in variety PBW-226 $(101.67 \mathrm{~cm})$ at par with HD-2967 (99.87 $\mathrm{cm}$ ) as compared to late sowing and other varieties. Plant height is mainly controlled by the genetic makeup, but it is also affected by environmental conditions. This attributed to maximum period of low temperature and short photoperiod was available for vegetative growth to $26^{\text {th }}$ November sown crop in comparison to late sowing. The height of the plants appears to be modified by the adverse environmental conditions. The findings of this investigation were similar with those observed by Behera (1994); Shahzad et al. (2007);
Tomar et al. (2014); Kumar (2016).

Number of tillers plant ${ }^{-1}$ and reproductive tillers plant ${ }^{-1}$ was not significantly influenced by dates of sowing and verities. This indicates the close genetic variation among five verities taken for experiment. Management practices such seeding rate and $\mathrm{N}$ application timing can influence tiller development (Bauer et al., 1984; Tilley et al., 2015).

The number of spike plant ${ }^{-1}$ of wheat was influenced by different sowing intervals and varieties. It is apparent from the results that the number of spike plant ${ }^{-1}(7.84)$ was maximum in the crop was sown on $26^{\text {th }}$ November, followed by decrease in average number of spike plant ${ }^{-1}$ with delayed sowing. This indicated that the differences in the spike per plant of wheat were non-linearly associated sowing dates. Thus, crop sown in the first and second fortnight of November could produce many spikes. Among varieties, HD-2967 produced maximum spikes plant ${ }^{-1}(7.40)$.

The results for the effect of sowing dates and varieties 
indicated that no significant difference for spike length of wheat. In contrary, the results pertaining to spike length of wheat as influenced by various sowing dates were found significant in the findings of Vahid et al. (2010). Similarly, the number of grains per spike was non-significantly influenced by varied dates of sowing and varieties. These results are in contrary with the findings of Shahzad et al. (2002); Tahir et al. (2009).

Days to maturity in wheat were influenced by dates of sowing and varieties, the results are presented in the Table 2 . The crop sown on $26^{\text {th }}$ November took significantly maximum 126.90 days, followed by $11^{\text {th }}$ December and $25^{\text {th }}$ December. The variety, PBW- 226 took minimum 112.50 days reach at maturity and HD-2967, too late i.e. 120.83 days. The maturity in plant delayed with timely sown crop, the first planted crop was exposed to favourable weather during the whole life cycle and thus the different phases of plant life could be completed at appropriate timing and under later sown condition the plant was forced to maturity because of sudden rise in temperature. These results are in close conformity with the finding of Kumar (2016); Gupta et al. (2017) who have also reported delayed maturity with timely sown crop.

The dates of sowing had significant influence on grain yield of wheat which had close association among varieties. Highest grain yield (41.51 q ha-1) was recorded in crop sown on November $26^{\text {th }}$ and in variety HD- 2967. The higher yields in timely sown crop in the month of November might be due to the reason that the crop received optimum environmental conditions for crop growth and get more time for attaining different phenophases. Grain yield is influenced by date of sowing and varieties as reported by Sial et al., 2010; Mumtaz et al., 2015.

The test weight of grains was significant due to varied sowing dates and among varieties. Maximum test weight of grains (38 g) was recorded on November $26^{\text {th }}$ sowing date and in variety HD-3086 at par with HD-2967. This may be due to the production of more number of grains ear ${ }^{-1}$ with lighter weight. The earlier sowing resulted in better development of the grains due to longer growing period. The results are in accordance with the findings of Shahzad et al. (2007).

The straw yield and biological yields of wheat were influenced by dates of sowing. The results showed that straw yield and biological yields were significantly decreased with delayed sowing from $26^{\text {th }}$ November onwards. These findings are in agreements with those of Wajid et al. (2004). Whereas, among varieties, there was no significant difference for straw and biological yields that might be due to close genetic variation. This is in contrary to findings of Fayed et al. (2015) who also found significant variation in straw yield of different varieties.

The data on harvest index of wheat was influenced by dates of sowing which sowed significant decrease in harvest index with delayed sowing from $26^{\text {th }}$ November onwards. However, all varieties were found at par for harvest index. Early sowing enhanced biomass accumulation over late sowing reported by Wajid et al. (2004).

\section{Conclusion}

It may be concluded based on findings that the variety, HD-2967 is suggested as promising one if sown on from $2^{\text {nd }}$ fortnight of November to $2^{\text {nd }}$ fortnight of December and PBW226 for late sown conditions under Western Uttar Pradesh in order to obtain higher yield potential.

\section{References}

Abbas, G., Younis, H., Naz, S., Fatima, Z., Atique-urRehman, Hussain, S., Ahmed, M., Ahmad, S., 2019. Effect of planting dates on agronomic crop production. In: Hasanuzzaman, M. (Eds), Agronomic Crops. Springer, Singapore. https://doi.org/10.1007/978-98132-9151-5_8.

Akhtar, M., Cheema, M.S., Jamil, M., Ali, L., 2006. Effect of time of sowing on some important characters of wheat, Triticum aestivum genotypes. Journal of Agricultural Research 44, 255-261.

Ali, M.A., Ali, M., Din, Q.M., 2004. Determination of grain yield of different wheat varieties as influenced by planting dates in agro-ecological conditions of Vehari. Pakistan Journal of Life and Social Sciences 2(1), 5-8.

Bauer, A., Frank, A.B., Black, A.L., 1984. Estimation of spring wheat leaf growth rates and anthesis from air temperature. Agronomy Journal 76, 829-835.

Behera A.K., 1994. Response of wheat (Triticum aestivum) varieties to sowing dates. Indian Journal of Agronomy 39(1), 171-173.

DES, 2020. Agricultural statistics at glance 2020. Directorate of Economics and Statistics. Government of India.

Fayed, T.B., Eman, I.E.S., Mosaad, K.H., Ahmed, M., 2015. Evaluation and prediction of some wheat cultivars productivity in relation to different sowing dates under North Sinai region conditions.Annals of Agricultural Science 60(1), 11-20.

Gupta, S., Singh, R.K., Sinha, N.K., Singh, A., Shahi, U.P., 2017. Effect of different sowing dates on growth and yield attributes of wheat in Udham Singh Nagar district of Uttarakhand, India. Plant Archives 17, 232-236.

Jessop, R.S., Lvins, J.D., 1970. The effect of date of sowing on the growth and yield of spring cearals. Journal of Agricultural Science 75, 533-557.

Joshi, A.K., Rani, B., Singh, M.P., 1992. Technology for late sown wheat in Eastern Uttar Pradesh. Indian Farming 42, 15.

Kumar, A.V., Singh, J., Kumar, L., Kumar, R., Kumar, P., Chand, P., 2017. Genetic variability and diversity analysis for yield and its components in wheat (Triticum aestivum L.). Indian Journal of Agricultural Research 51(2), 128-134.

Kumar, B., 2016. Genetic improvement trend analysis for end-use quality characteristics among wheat cultivars 
of North-Western India. Indian Journal of Genetics and Plant Breeding 76(2), 137-143.

Kumar, S., Bangarwa, A.S., Kadian, V.S., 2000. Response of wheat varieties to sowing dates and nitrogen levels. Annales Agriculture and Biological Research 5, 99-103.

Mumtaz, M.Z., Aslam, M.M., Hafiz, N., Akhtar, U., Ali, B., 2015. Effect of various sowing dates on growth, yield and yield components of different wheat genotypes.American Eurasian Journal Agricultural \& Environment Science 15(11), 2230-2234, DOI: 10.5829.

Ouda, S.A., El-Marsafawy, S.M., El-Kholy, M.A., Gaballah, M.S., 2005. Simulating the effect of water stress and different sowing dates on wheat production in South Delta. Journal of Applied Sciences Research 1, 268-276.

Radmehr, M., Ayeneh, G.A., Mamghani, R., 2003. Responses of late, medium and early maturity read wheat genotypes to different sowing date I. Effect of sowing date on phonological, morphological, and grain of four bred wheat genotypes. Iranian Journal of Seed Research 21, 175-189.

Shah, W.A., Bakht, J., Ullah, T., Khan, A.W., Zubair, M., Khakwani, A.A., 2006. Effect of sowing dates on the yield and yield components of different wheat varieties. Journal of Agronomy 5, 106-110.

Shahzad, K., Bakht, J., Shah, W.A., Shafi, M., Jabeen, N., 2002. Yield and yield components of various wheat cultivars as affected by different sowing dates. Asian Journal of Plant Sciences 1(5), 522-525.

Shahzad, M.A., Din, W.U., Sahi, S.T., Khan Ehsanullah, M.M., Ahmad, M., 2007. Effect of sowing dates and seed treatment on grain yield and quality of wheat. Pakistan Journal of Agricultural Science 44(4), 581-583.

Sial, M.A., Arain, M.A.,Dahot, M.U., Markhand, G.S., Laghari, K.A., Mangrio, S.M., Mirbahar, A.A., Naqvi, M.H., 2010. Effect of sowing dates on yield and yield components on mutant-cum-hybrid lines of bread wheat. Pakistan
Journal of Botany 42(1), 269-277.

Stapper, M., Fischer, R.A., 1990. Genotype, sowing date and plant spacing influence on high-yielding irrigated wheat in southern New South Wales. I. Phase development canopy growth and spike production. Australian Journal of Agricultural Research 41, 997-1019.

Tahir, M., Ali, M.A., Hussain, N.A., Khalif, F., 2009. Effect of different sowing dates on growth and yield of wheat (Triticum aestivum L.) verities in district Jhang, Pakistan. Pakistan Journal of Life Society Science 7(1), 66-69.

Tilley, M.S., Heiniger, R.W., Crozier, C.R., 2015. Improving winter wheat yield in the Southeast by examining the development and mortality of fall, winter, and wpring tillers using different seed populations and nitrogen management strategies. (Unpublished master thesis.) North Carolina State Univ. Library, Raleigh. http://www. lib.ncsu.edu/resolver/1840.16/10563

Tomar, S.P.S., Tomar, S., Srivastava, S.C., 2014. Yield and yield component response of wheat (Triticum aestivum L.) genotypes to different sowing dates in Gird region of Madhya Pradesh.International Journal of Farm Sciences 4(2), 1-6.

Vahid, K., Nejad, G.K., Ghasem, M.N., Khatoon, Y., 2010. The effect of sowing dates on yield and yield components of wheat (Triticum aestivum L.) cultivars.International Journal of Agronomy and Plant Production 1(3), 77-82.

Wajid, A., Hussain, A., Ahmad, A., Goheer, A.R., Ibrahim, M., Mussaddique, M., 2004. Effect of sowing date and plant population on biomass, grain yield and yield components of wheat. International Journal of Agriculture and Biology 1560-8530/2004/06-6-1003-1005. 